\section{Heat-retentive Films for Increasing Soil Temperatures during Solarization in a Humid, Cloudy Environment}

\author{
Carlene A. Chase and Thomas R. Sinclair \\ U.S. Department of Agriculture, Agricultural Research Service, Agronomy \\ Physiology and Genetics Laboratory, P.O. Box 110965, University of Florida, \\ Gainesville, FL 32611 \\ Daniel O. Chellemi ${ }^{1}$ and Stephen M. Olson \\ North Florida Research and Education Center, University of Florida, Quincy, \\ FL 32351
}

\section{James P. Gilreath}

Gulf Coast Research and Education Center, University of Florida, Bradenton, FL 34203

\section{Salvadore J. Locascio \\ Horticultural Sciences Department, University of Florida, Gainesville, FL 32611}

Additional index words. methyl bromide alternatives, soil solarization, polyethylene mulch

\begin{abstract}
Although summer soil solarization is a viable technique for the control of soilborne pests, periods of cloudy skies and high rainfall typical of the southeastern United States limit the heating of soils. This study was devised to evaluate whether polyethylene films designed for improved heat conservation could increase soil solarization temperatures under humid environmental conditions. Soil solarization was conducted in Summer 1996 at Quincy, Gainesville, and Bradenton: located in north, north central, and west central Florida, respectively. Temperatures at soil depths of 5,10 , and $25 \mathrm{~cm}$ were higher under clear solarization films than under black polyethylene. A clear, thermal-infrared absorbing film (TIR) was consistently more effective in increasing soil temperature than was a double-layered, clear bubble film or a $30 \mu \mathrm{m}$ clear, low-density polyethylene film. Soil temperatures under all film types were reduced by rainfall, but remained highest under TIR film. On cloudy days with light rainfall, temperatures under TIR film exceeded $45^{\circ} \mathrm{C}$ at $5 \mathrm{~cm}$ depth. Soil temperatures rose rapidly when rainy weather was followed by a clear day. Cumulative exposure to temperatures $\geq 45$ and $50^{\circ} \mathrm{C}$ was greater with the TIR film than with the other films, indicating that it has the greatest potential for soil solarization in humid climates.
\end{abstract}

With the impending ban on the production and importation of methyl bromide in the year 2005 , soil solarization has been identified as an attractive nonchemical approach to soil disinfestation(Chellemi etal., 1997). Although the benefits of soil solarization have been demonstrated in arid climates (Katan et al., 1976; Lodha etal., 1997; Stapleton and DeVay, 1983), the feasibility of soil solarization in humid, cloudy environments has been questioned (Chellemi et al., 1993; McSorley and Parrado, 1986; Overman and Jones, 1986). In Florida, frequent cloud cover and rainfall dur-

\footnotetext{
Received for publication 5 Nov. 1998. Accepted for publication 22 Mar. 1999. Florida Agricultural Experiment Station, Journal Series No. R-06870. Mention of trade names or commercial products in this article is solely for the purpose of providing specific information and does not imply recommendation or endorsement by the U.S. Dept. of Agriculture. The cost of publishing this paper was defrayed in part by the payment of page charges. Under postal regulations, this paper therefore must be hereby marked advertisement solely to indicate this fact.

${ }^{1}$ Current address: USDA-ARS, 2199 South Rock
} Road, Ft. Pierce, FL 34945. ing the summer, and high water tables, can prevent the development of sufficiently high temperatures under the solarization film. Despite this, the use of clear low-density polyethylene and green photoselective films has been effective in several studies in Florida. Overman and Jones (1986) found that summer soil solarization was potentially an effective alternative to chemical fumigation for the control of soilborne pests of tomato (Lycopersicon esculentum Mill.) in Florida. With rainfall occurring on $60 \%$ of the $63 \mathrm{~d}$ of solarization, soil solarization decreased nutsedge (Cyperus spp.) and nematode densities such that tomato yields were not significantly improved with a treatment in which methyl bromide was applied after soil solarization (McSorley and Parrado, 1986). Soil solarization reduced the incidence of phytoparasitic nematodes and soilborne pathogens of tomato (Chellemi et al., 1993, 1994, 1997; Overman, 1985), and was as effective as methyl bromide in controlling the sting nematode in strawberry (Fragaria $\times$ ananassa Duchesne) (Overman et al., 1987).

Lamberti and Basile (1991) have discussed the characteristics of plastic films that can improve soil heating. Solarization film should allow maximum transmission of visible solar radiation and shortwave infrared (IR) radiation and minimize energy losses from the soil. The energy losses occur by means of thermic conduction, thermic convection, and irradiation losses through medium-longwave IR radiation. In most previous studies of soil temperature under solarization, clear, low-density polyethylene films were generally used (Mahrer, 1979; Mahrer et al., 1984). Such films are poor barriers to medium-long wave IR radiation. While other alternative films have been evaluated (Chellemi et al., 1993, 1994, 1997; Ham et al., 1993), the formulation and evaluation of heat-retentive films dedicated to soil solarization have not.

There are at least two possibilities for increasing the heat retention of clear, low-density polyethylene films. One option is to reduce the transmittance of radiation through the film in the thermal IR wavebands. Thermal IR radiation is emitted from all surfaces as a function of their temperature, and is usually the major mechanism for heat loss. For a surface such as soil, with a temperature of 40 ${ }^{\circ} \mathrm{C}$, the wavelength of peak radiation loss is 9.3 $\mu \mathrm{m}$, and most of the reradiated energy is in the waveband of 6 to $20 \mu \mathrm{m}$ (Sinclair and Gardner, 1998). Conventional polyethylene films readily transmit these thermal IR wavebands, so virtually all of the radiant energy is lost to the environment. Calculations have shown that decreasing the transmittance of films in the thermal IR wavebands would increase soil temperature (Ham and Kluitenberg, 1994; Wu et al., 1996). Additives such as inorganic salts can be incorporated into polyethylene films to increase the absorption in the thermal IR wavelengths (Lamberti and Basile, 1991; Stevens et al., 1991).

A second option for increasing heat retention during soil solarization is to reduce convective heat loss from the planting bed. Generally, polyethylene mulches are $\approx 25 \mu \mathrm{m}$ thick, so that heat is readily conducted through the film. The temperature of the outer surface of such a film is the same as that of the air under the film. As a result, heat is readily convected into the atmosphere from the solarization system at the outer surface of the film. When using two layers of film, heat must first be transferred from the inner to the outer layer of film before it is convected to the atmosphere. In calculating the energy balance of polyethylene mulches, Ham and Kluitenberg (1994) suggested that increased resistance to convective heat losses increases soil temperatures under a clear mulch.

The temperatures achieved and the duration of high temperature are critical determinants of the effectiveness of soil solarization. Pullman et al. (1981) showed that there is a logarithmic relationship between time and temperature for pathogen mortality. For example, exposure to $50^{\circ} \mathrm{C}$ for $10 \mathrm{~min}$ killed cultures of Rhizoctonia solani Kuehn, whereas $14 \mathrm{~d}$ were required at $39{ }^{\circ} \mathrm{C}$. In Florida, Chellemi et al. (1993) conducted solarization for $32 \mathrm{~d}$ with a green photoselective film and obtained maximum soil temperatures of 49.5, 46.0, and 40.5 
${ }^{\circ} \mathrm{C}$ at soil depths of 5,15 , and $25 \mathrm{~cm}$, respectively. While densities of Fusarium oxysporum Schlechtend.:Fr.f.sp. radicis-lycopersici W.R. Jarvis \& Shoemaker and F. o. lycopersici (Sacc.) W.C. Snyder \& H.N. Hans. were suppressed only to a depth of $5 \mathrm{~cm}$, there were significant reductions in the densities of Pseudomonas (=Ralstonia) solanacearum (Smith), phytoparasitic nematodes and Phytophthora nicotianae Breda de haan var parasitica (Dastur) to depths of 15, 20, and 25 $\mathrm{cm}$, respectively. Horowitz et al. (1983) found that soil solarization effectively controlled weeds when maximum soil temperatures were $\geq 45{ }^{\circ} \mathrm{C}$, and that control improved as the number of days with temperatures above that threshold increased. In laboratory studies, we confirmed the importance of the $45^{\circ} \mathrm{C}$ threshold in killing nutsedge tubers (C. esculentus $\mathrm{L}$. and $C$. rotundus L.). Exposure to daily oscillating soil temperatures with maxima exceeding $45^{\circ} \mathrm{C}$ over a 2 -week period resulted in complete tuber mortality (Chase et al., 1999). We have previously reported on improved nutsedge control with TIR film vs. conventional clear film (Chase et al., 1998). Foliar scorching was also an important mechanism for controlling nutsedge shoots that emerged from tubers that were not exposed to lethal temperatures.

The objectives of this research were to 1 ) verify experimentally the effect on soil temperature of the use of a high-transparency, thermal-IR absorbing film during solarization, and 2) determine whether decreasing convective heat loss by using a double-layered mulch formulated as a bubble-wrap film would further increase soil temperatures. Field experiments designed for evaluating alternatives to methyl bromide fumigation were used to monitor soil temperatures under several polyethylene films installed on planting beds prior to crop transplanting. Soil solarization was conducted during summer months at three geographic locations where cloudy, rainy conditions prevailed.

\section{Materials and Methods}

Solarization environments. Soil solarization was conducted in Summer 1996 at three locations within the state of Florida (Quincy, Gainesville, and Bradenton) that provided a diversity of soil and weather conditions. At each location, planting beds were formed mechanically prior to application of the various films. Beds were $0.2 \mathrm{~m}$ high and $0.9 \mathrm{~m}$ wide, and were oriented in a north-south direction. Films were applied using machinery that laid the film over the beds and covered the edges of the film with soil next to the base of the bed.

The Quincy experimental site was located at the North Florida Research and Education Center, where the soil was a Ruston loamy sand (fine-loamy, siliceous, thermic, Typic Kandiudult). Overhead irrigation was employed prior to mulching, since soil moisture is required for efficient heat transfer during solarization and for activating dormant structures and propagules. Solarization was initi- ated on 6 June and soil temperatures were measured from 9 June to 10 July. At Gainesville, solarization films were installed on 10 July on a Millhopper fine sand (loamy, siliceous, hyperthermic, Grossarenic Paleudults). There had been heavy rainfall $3 \mathrm{~d}$ prior to mulching. Soil temperatures were measured from 14-23 July and 2-14 Aug. At the Gulf Coast Research and Education Center, Bradenton, soil solarization was conducted on an EauGallie fine sand (sandy, siliceous, hyperthermic Alfic Haplaquods). This site was subsurface irrigated throughout the solarization period to maintain a high water table for irrigation of the subsequent tomato crop. At the other two locations, moisture was replenished only by rainfall. Solarization was initiated on 17 July and soil temperatures were measured from 19 July to 18 Aug.

Films. At all three locations a $30 \mu \mathrm{m}$ clear low-density polyethylene film (CLR) (AEP Industries, Hackensack, N.J.) was compared with a $100 \mu \mathrm{m}$ thermal-IR absorbing (TIR) film, manufactured by AT Plastics (Edmonton, Alberta, Canada) specifically for this test. The film was clear and transmitted $>95 \%$ in the solar radiation wavebands. Importantly, in the wavebands near the peak of thermal IR reradiation for a soil, the transmittance of the film was only $\approx 25 \%$, i.e., it absorbed $\approx 75 \%$ (Fig. 1). Its low transmittance in the thermal IR wavebands is in marked contrast to the CLR film (Fig. 1). Bubble film, stabilized against ultraviolet radiation, was manufactured (Tenneco Packaging, Glens Falls, N.Y.) from two layers of $75 \mu \mathrm{m}$-thick polyethylene film, using the configuration of the commercial wrapping material with a bubble height of 3.2 $\mathrm{mm}$ and a diameter of $10 \mathrm{~mm}$. The bubble side of the film was placed next to the soil so that the smooth surface was exposed to the atmosphere. The film was highly transmissive of visible radiation but the bubble configuration resulted in considerable backscattering of solar radiation. This film was used at Quincy and Bradenton but not at Gainesville. At all three sites a black film was also included in the study. At Gainesville and Bradenton, $38 \mu \mathrm{m}$ conventional, embossed, black film (BLK) (Edison Plastics, Williamsburg, Va., at Gainesville, and Consolidated Thermoplastics, Harrington, Del., at Bradenton) was used; while at Quincy, the black film was a $30-\mu \mathrm{m}$ gas-impermeable black film (Bromotec film; Lawson Mardon Packaging, Workington, Cumbria, U.K.).

Temperature measurements. Soil temperatures were measured under each film using dataloggers (modelCR10 or CR10X; Campbell Scientific, Logan, Utah) equipped with copper-constantan thermocouples positioned at $0-, 5-, 10-$, and 25-cm depths equidistant from the edges of the bed and at least $1 \mathrm{~m}$ from the end of the plot. At Bradenton and Gainesville soil temperatures were monitored at 30-min intervals at all depths. At Quincy, because of limitations in data storage capacity, temperatures at the surface and at 5-cm depth were logged at half-hour intervals and temperatures at 10 - and 25 -cm depths were measured hourly. Soil temperature was measured for one replication of each film at each location and data for the solarization period were summarized to obtain the daily maximum, mean daily maximum, and the overall mean temperature for each location. The cumulative hours of exposure to temperatures $\geq 45$ and $50^{\circ} \mathrm{C}$ were also calculated for 30 consecutive days of soil solarization at Quincy and at Bradenton.

\section{Results and Discussion}

Diurnal variation in soil temperature. The daily cycle of soil temperature under the films was characteristic of a bare soil (Wu et al., 1996), with the greatest variation through the daily cycle occurring at the soil surface. Diurnal fluctuation in temperature at the soil surface on a nearly clear day was typically $>30^{\circ} \mathrm{C}$ (Fig. 2). The daily variation in temperature decreased as soil depth increased, such that it was only $\approx 5^{\circ} \mathrm{C}$ at a depth of $25 \mathrm{~cm}$ (Fig. 2). Also, the times at which the maximum and minimum temperature occurred were delayed as soil depth increased. Maximum and minimum temperatures at the surface occurred at

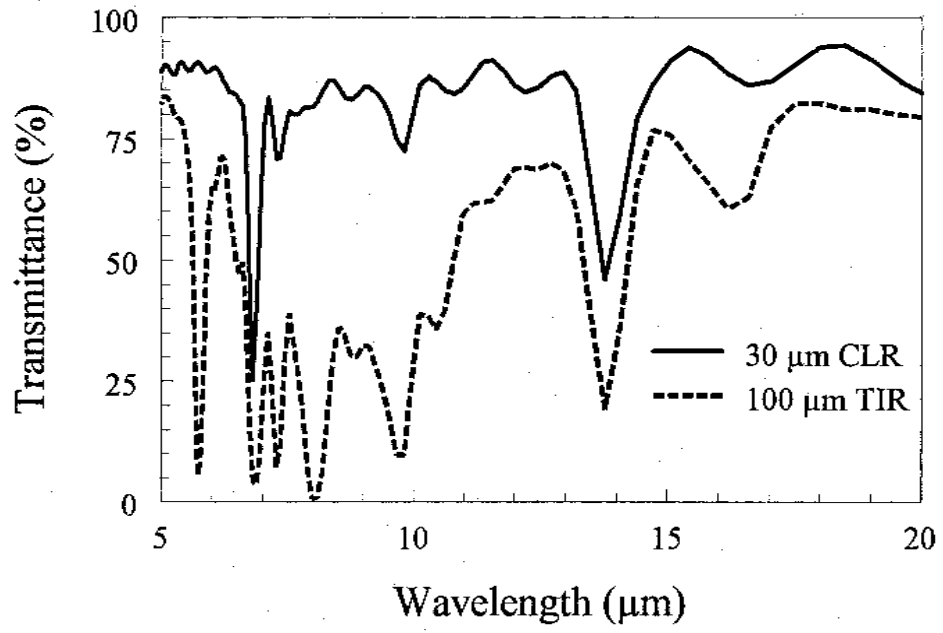

Fig. 1. Comparative transmittance of infrared radiation of a clear, low-density polyethylene film (CLR) vs. a heat-conserving thermal-infrared absorbing film (TIR). 
$\approx 1300$ and $0600 \mathrm{HR}$, respectively, while at the 25-cm depth they occurred at 1900 and 0900 HR, respectively.

Soil temperatures at midday were higher under the three clear solarization films than under conventional black film (Fig. 2). Temperature differences with the various films were greater at the surface and diminished with depth. Among the three solarization films used at the Bradenton location, the TIR film resulted in the highest soil temperatures at all soil depths. There was little difference in soil temperatures at night among the four films except for the slightly higher temperatures at the soil surface under the bubble film.

Environmental sensitivity. A concern in undertaking soil solarization in a cloudy, humid environment is the influence of reduced solar radiation. Rainfall, in particular, presents a problem because both the cloudy conditions and the temperature of the rain can readily depress soil temperatures. However, temperatures at and near the soil surface recovered rapidly following rainfall events. Temperatures measured at the 5-cm depth for a sequence of $4 \mathrm{~d}$ associated with rainfall at Quincy (Fig. 3) illustrated the rapid temperature recovery. The first day was overcast with $10 \mathrm{~mm}$ of rainfall. The second and third days were less overcast but light showers did occur. No rain occurred on the fourth day. The soil temperature on each day appeared to be nearly independent of that on the previous day, with rapid recovery from the effects of rainy conditions. In this example, temperatures under all films were very low on the first day of rainfall but reached reasonably high temperatures on the following $3 \mathrm{~d}$.

As observed previously, all three solarization films raised soil temperatures substantially more than did black film (Fig. 3), with TIR film being the most effective. The 3 to 4 ${ }^{\circ} \mathrm{C}$ higher temperature with the TIR film resulted in temperatures $>45^{\circ} \mathrm{C}$ under this film, even on the days of light rainfall. The relative temperatures among the various films during the night at Quincy (Fig. 3) differed from those at Bradenton (Fig. 2). At Bradenton the soil temperatures with all films were within $0.4^{\circ} \mathrm{C}$ at 5-cm depth; at Quincy, minimum soil temperatures under TIR film were $\approx 2{ }^{\circ} \mathrm{C}$ higher than under the bubble film, which had the next highest night temperatures. This result might be related to the fact that the soil at Bradenton was kept in a very moist state by continuous subsurface irrigation so that heat conduction within the soil was high. At Quincy, the soil was not irrigated during solarization so that conduction was lessened and the temperature advantage gained by the TIR absorbing film during the day was preserved through the night.

Soil surface temperatures. The highest soil surface temperatures occurred at Quincy (Table $1)$, where the maximum temperature of the solarization period with all films exceeded 67 ${ }^{\circ} \mathrm{C}$ and the mean maximum daily temperature exceeded $58^{\circ} \mathrm{C}$. The next highest soil surface temperatures occurred at Gainesville with a maximum $>63^{\circ} \mathrm{C}$ and a mean daily maximum of $52{ }^{\circ} \mathrm{C}$ or greater. The soil at these two locations was not rewetted during the solariza-
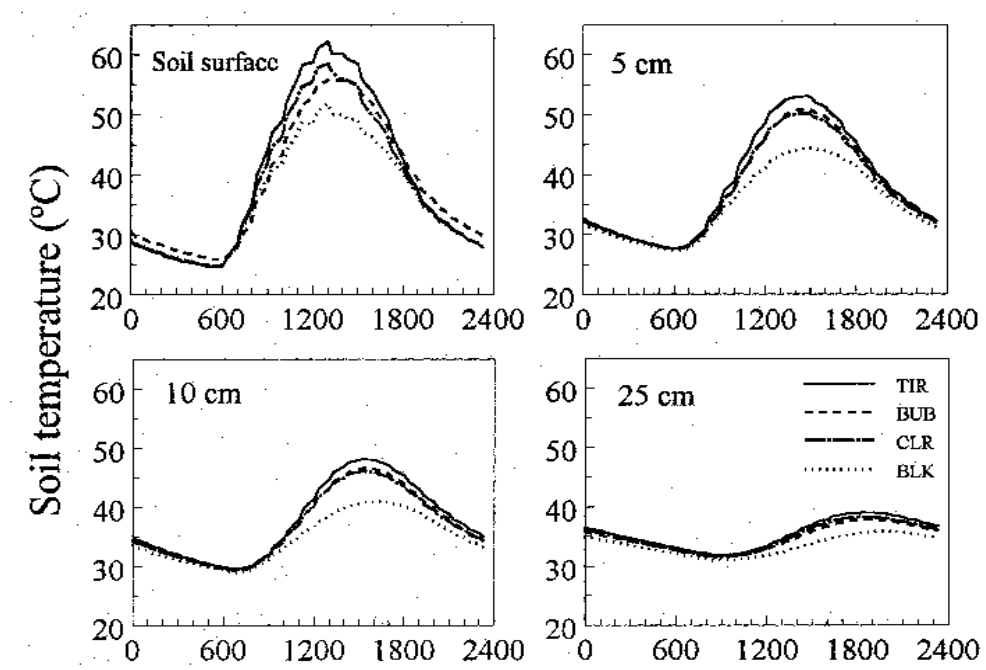

\section{Time (h)}

Fig. 2. Diurnal temperature changes measured at four soil depths for four film types at Bradenton, Fla., on a rain-free day (27 July 1996). Polyethylene mulches were: $100 \mu \mathrm{m}$ thermal-infrared absorbing film (TIR), UV-stabilized bubble film manufactured with two layers of $75 \mu \mathrm{m}$-thick polyethylene film (BUB), 30 $\mu \mathrm{m}$ clear low-density polyethylene film (CLR), and $38 \mu \mathrm{m}$ conventional, embossed black film.

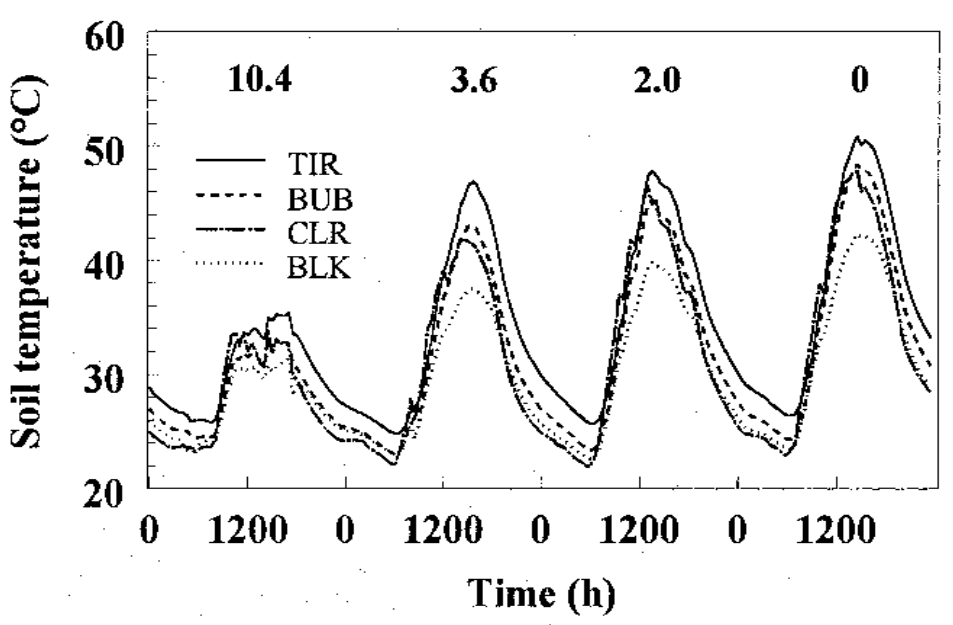

Fig. 3. Effect of rainfall on soil temperatures under four polyethylene mulches at a 5-cm depth at Quincy, Fla., 8 to 11 June 1996 . Polyethylene mulches were: $100 \mu \mathrm{m}$ thermal-infrared absorbing film (TIR), UVstabilized bubble film manufactured with two layers of $75 \mu \mathrm{m}$-thick polyethylene film (BUB), $30 \mu \mathrm{m}$ clear low-density polyethylene film (CLR), and $30 \mu \mathrm{m}$ gas-impermeable black film. Numbers above curves indicate rainfall $(\mathrm{mm})$ each day.

tion period except by rainfall, so that the loss of moisture at the soil surface may have contributed to these high temperatures. At Bradenton, where the soil was subsurface irrigated, the maximum soil surface temperature was lower than at the other two locations, except under the TIR film. The maximum temperature under the TIR film exceeded 65 ${ }^{\circ} \mathrm{C}$ while temperatures were $<60{ }^{\circ} \mathrm{C}$ under the other three films. Similar differences among the films were observed at Bradenton in mean daily maximum temperatures.

At Gainesville and Bradenton, higher soil surface temperatures were obtained with the solarization films than with the black film. At both of these locations, the TIR film provided the highest mean daily maximum temperature and the black film resulted in the lowest. There was little difference among the four films at
Quincy, but this may have been due to the drying of the soil surface at this location. Even under the black film, soil surface temperatures were high at Quincy. The difference in soil heating characteristics is illustrated by the mean daily maximum temperatures at the soil surface under the black film, which were 61.5, 51.9 , and $48.8^{\circ} \mathrm{C}$ at Quincy, Gainesville, and Bradenton, respectively.

Soil temperature at various depths. Solarization films consistently produced higher soil temperatures than black films at all three locations (Table 1). At the 5-cm depth, the mean daily maximum temperature under the solarization films exceeded $45^{\circ} \mathrm{C}$, and was $\approx 5^{\circ} \mathrm{C}$ lower under the black film. The highest mean daily maximum temperatures were recorded with TIR film at each of the three locations. Similarly, higher soil temperatures were ob- 
Soll Management, Fertilization, \& Irrigation

Table 1. Influence of polyethylene mulch films ${ }^{2}$ and soil depth on soil temperatures at Quincy, Gainesville, and Bradenton, Fla., in 1996.

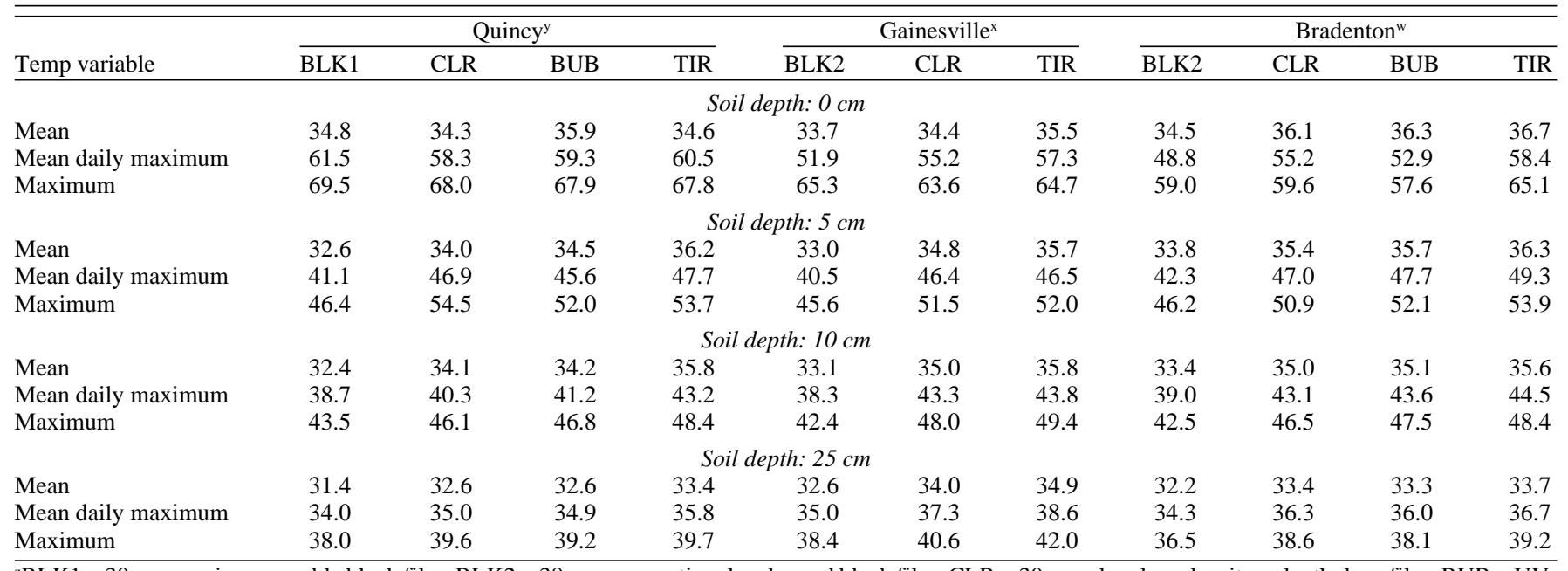

${ }^{2}$ BLK1 $=30-\mu \mathrm{m}$ gas-impermeable black film; BLK2 = 38- $\mu \mathrm{m}$ conventional embossed black film; CLR = 30- $\mu \mathrm{m}$ clear low-density polyethylene film; BUB = UVstabilized bubble film manufactured with two layers of $75-\mu \mathrm{m}$-thick polyethylene film; and TIR $=100-\mu \mathrm{m}$ thermal-infrared absorbing film.

y9 June-10 July.

${ }^{x} 14-23$ July and 2-14 Aug.

w19 July-18 Aug.

tained with the solarization films than with the black films at 10-cm depth. At this depth, the differences among the films were not as great as at the shallower soil depth, and, although maximum temperatures achieved under the solarization films exceeded $45^{\circ} \mathrm{C}$, the mean maximum temperature did not. Temperatures were highest under the TIR film. The difference in soil temperatures under black film vs. solarization films was much less at the $25-\mathrm{cm}$ depth than at shallower depths, but temperatures among the solarization films were very similar.

Cumulative time of exposure to high temperature. The cumulative exposure times during which temperatures were $\geq 45$ and $50{ }^{\circ} \mathrm{C}$ were consistently higher with solarization films than with black films (Table 2) at Quincy and Bradenton. (Data were not tabulated for Gainesville because the temperature record was not continuous). The black films were the only films under which soil temperatures at 10 $\mathrm{cm}$ did not rise to $45^{\circ} \mathrm{C}$. The TIR film provided the highest cumulative exposure at all sites. At the $10 \mathrm{~cm}$-depth at Quincy, cumulative expo-

sure was 38 and $48 \mathrm{~h}$ greater with TIR film than with bubble and CLR films, respectively. Similarly, for the 10-cm depth at Bradenton, cumulative exposure was 18 and $30 \mathrm{~h}$ greater with TIR film than with bubble and CLR films, respectively. There was no consistent difference between the bubble and CLR films across the two locations.

Conclusions. Our current studies demonstrate that the use of heat-retentive TIR film may have potential for enhancing the utility of soil solarization under cloudy, humid environments. While the temperature advantage varied among locations and soil depths, the TIR film was the most effective of the solarization films in increasing soil temperatures. The mean daily maximum temperatures at each of the three locations was at least 57,46 , and $43{ }^{\circ} \mathrm{C}$ for the surface, $5-\mathrm{cm}$, and $10-\mathrm{cm}$ depths, respectively. The temperatures in the upper 10 $\mathrm{cm}$ of soil were sufficiently high to be potentially lethal to mesophilic pathogens and weed propagules, and also the cumulative time of exposure to temperatures exceeding the threshold were highest with TIR films. More study is

Table 2. Influence of polyethylene mulch and soil depth on cumulative hours of exposure to temperatures $\geq 45^{\circ} \mathrm{C}$ and $50^{\circ} \mathrm{C}$ at Quincy, Fla., and Bradenton, Fla., over 30 consecutive days of soil solarization.

\begin{tabular}{|c|c|c|c|c|c|}
\hline \multirow[b]{2}{*}{ Location } & \multirow{2}{*}{$\begin{array}{c}\text { Soil depth } \\
(\mathrm{cm})\end{array}$} & \multicolumn{4}{|c|}{ Polyethylene film ${ }^{z}$} \\
\hline & & Black & Clear & Bubble & TIR \\
\hline & & \multicolumn{4}{|c|}{ Cumulative hours $\geq 45^{\circ} \mathrm{C}$} \\
\hline \multirow[t]{3}{*}{ Quincy } & 0 & 173 & 175 & 181 & 181 \\
\hline & 5 & 12 & 107 & 91 & 129 \\
\hline & 10 & 0 & 14 & 24 & 62 \\
\hline \multirow[t]{4}{*}{ Bradenton } & 0 & 92 & 171 & 166 & 195 \\
\hline & 5 & 15 & 100 & 111 & 133 \\
\hline & 10 & 0 & 26 & 56 & 38 \\
\hline & & \multicolumn{4}{|c|}{ Cumulative hours $\geq 50^{\circ} \mathrm{C}$} \\
\hline \multirow[t]{2}{*}{ Quincy } & 0 & 134 & 133 & 140 & 146 \\
\hline & 5 & 0 & 28 & 16 & 44 \\
\hline \multirow[t]{2}{*}{ Bradenton } & 0 & 27 & 100 & 90 & 130 \\
\hline & 5 & 0 & 7 & 22 & 46 \\
\hline
\end{tabular}

${ }^{2} 30-\mu \mathrm{m}$ gas-impermeable black film (38- $\mu \mathrm{m}$ conventional embossed black film at Bradenton), 30- $\mu \mathrm{m}$ clear low-density polyethylene film, UV-stabilized bubble film manufactured with two layers of $75-\mu \mathrm{m}$-thick polyethylene film, and 100- $\mu \mathrm{m}$ thermal-infrared absorbing (TIR) film, respectively. warranted with oscillating temperatures to determine lethal temperatures and durations required for specific soilborne pests and pathogens. The bubble film, which was tested as a means of reducing convective heat loss from the solarized beds, failed to increase soil temperatures above that achieved with a single layer of clear polyethylene film in virtually all comparisons. The backscattering of solar radiation as a result of the bubble configuration may have decreased its transmission to the soil. Further, the bulkiness of the bubble film makes it unattractive for commercial use.

Overall, these results indicate that TIR film can promote more effective soil heating than can CLR film. The enhanced capacity for soil heating with TIR film promotes conditions that are detrimental to soilborne pests, even when the background environment may be somewhat adverse for other films. Therefore, the use of TIR film in soil solarization appears to be a viable option for enhancing the control of soilborne pests in humid, subtropical environments. The efficacy of control has been documented for nutsedge (Chase et al., 1998, 1999) and additional information on pathogen control and tomato yield are subjects of a subsequent paper. The evaluation of TIR film for solarization in late summer and early fall for production of strawberry is in progress.

\section{Literature Cited}

Chase, C.A., T.R. Sinclair, and S.J. Locascio. 1999. Effects of soil temperature and tuber depth on Cyperus spp. control. Weed Sci. 47:467-472.

Chase, C.A., T.R. Sinclair, D.G. Shilling, J.P. Gilreath, and S.J. Locascio. 1998. Light effects on rhizome morphogenesis in nutsedges (Cyperus spp.): Implications for control by soil solarization. Weed Sci. 46:575-580.

Chellemi, D.O., S.M. Olson, and D.J. Mitchell. 1994. Effects of soil solarization and fumigation on survival of soilborne pathogens of tomato in northern Florida. Plant Dis. 78:1167-1172.

Chellemi, D.O., S.M. Olson, D.J. Mitchell, I. Secker, 
and R. McSorley. 1997. Adaptation of soil solarization to the integrated management of soilborne pests of tomato under humid conditions. Phytopathology 87:250-258.

Chellemi, D.O., S.M. Olson, J.W. Scott, D.J Mitchell, and R. McSorley. 1993. Reduction of phytoparasitic nematodes on tomato by soil solarization and genotype. J. Nematol. 25 (suppl.):800-805.

Davis, C.H. and R.S. Hawkins. 1943. Eradication and control of nut grass. Arizona Agr. Expt. Sta. Bul. 189.

Friesen, G.H. and A.S. Hamill. 1977. Sprouting and development of yellow nutsedge tubers. Can. J. Plant Sci. 57:509-514.

Ham, J.M. and G.J. Kluitenberg. 1994. Modeling the effect of mulch optical properties and mulchsoil contact resistance on soil heating under plastic mulch culture. Agr. For. Meteorol. 71:403-424.

Ham, J.M., G.J. Kluitenberg, and W.J. Lamont. 1993. Optical properties of plastic mulches affect the field temperature regime. J. Amer. Soc. Hort. Sci. 118:188-193.

Horowitz, M., Y. Regev, and G. Herzlinger. 1983 Solarization for weed control. Weed Sci. 31:170 179.

Katan, J., A. Greenberger, H. Alon, and A. Grinstein. 1976. Solar heating by polyethylene mulching for the control of diseases caused by soil-borne pathogens. Phytopathology 66:683-688.

Lamberti, F. and M. Basile. 1991. Improvement in plastic technology for soil heating, p. 309-330. In: J.E. DeVay, J.J. Stapleton, and C.L. Elmore (eds.). Soil solarization. FAO Plant Production and Protection Paper 109, Rome.

Lodha, S., S.K. Sharma, and R.K. Aggarwal. 1997. Solarization and natural heating of irrigated soil amended with cruciferous residues for improved control of Macrophomina phaseolina. Plant Pathol. 46:186-190.

Loustalot, A.J., T.J. Muzik, and H.J. Cruzado. 1954. Studies on nutgrass (Cyperus rotundus L.) and its control. Puerto Rico Federal Expt. Sta. Bul. 52.

Mahrer, Y. 1979. Prediction of soil temperature of a soil mulched with transparent polyethylene. J. Appl. Meteorol. 18:1263-1267.

Mahrer, Y., O. Naot, E. Rawitz, and J. Katan. 1984 Temperature and moisture regimes in soils mulched with transparent polyethylene. Soil Sci. Soc. Amer. J. 48:362-367.

McSorley, R. and J.L. Parrado. 1986. Application of soil solarization to Rockdale soils in a subtropical environment. Nematropica 16:125-140.

Overman, A.J. 1985. Off-season land management, soil solarization and fumigation for tomato. Proc. Soil and Crop Sci. Soc. Florida. 44:35-39.
Overman, A.J., C.M. Howard, and E.E. Albregts. 1987. Soil solarization for strawberries. Proc. Florida. State Hort. Soc. 100:236-239.

Overman, A.J. and J.P. Jones. 1986. Soil solarization, reaction, and fumigation effects on doublecropped tomato under full-bed mulch. Proc. Florida State Hort. Soc. 99:315-318.

Pullman, G.S., J.E. DeVay, and R.H. Garber. 1981. Soil solarization and thermal death: A logarithmic relationship between time and temperature for four soilborne plant pathogens. Phytopathology 71:959-964.

Sinclair, T.R. and F.P. Gardner. 1998. Principles of ecology in plant production. CAB Intl., Wallingford, U.K.

Stapleton, J.J. and J.E. DeVay. 1983. Response of phytoparasitic and free-living nematodes to soil solarization and 1,3-dichloropropene in California. Phytopathology 73:1429-1436.

Stevens, C., V.A. Khan, J.E. Brown, G.J.Hochmuth, W.E. Splittstoesser, and D.M. Granberry. 1991. Plastic chemistry and technology as related to plasticulture and solar heating of soil, p. 141158. In: J. Katan and J.E. DeVay (eds.). Soil solarization. CRC Press, Boca Raton, Fla.

Wu, Y., K.B. Perry, and J.B. Ristaino. 1996. Estimating temperature of mulched and bare soil from meteorological data. Agr. For. Meteorol. 81:299-323. 